\title{
EFFECTIVE QUANTITATIVE TECHNIQUES FOR PART-MACHINE FORMATION AND THEIR PERFORMANCE METRICS ON GT CELL OPERATION- A STUDY
}

\author{
S.A. Puviyarasu ${ }^{1}$ \\ ${ }^{I}$ Department of Mechanical Engineering, Dr.N.G.P Institute of Technology, Coimbatore, Affiliated to Anna \\ University-Chennai, Tamilnadu, India
}

\begin{abstract}
The main objective of this study is to analyze the effective part-machine formation and their performances matrices on GT cell operation. Cellular manufacturing is an application of group technology that has recently attracted the attention of manufacturing firms. The part-machine cell formation problem mainly minimizing the inter-cell, intra cell movement and maximize machine utilization. The paper presents a generalized approach for part-machine cell formation from a job shop using quantitative techniques in order to reduce set-up time, work-in-progress and lead times; leading to product quality and customer satisfaction.
\end{abstract}

Keywords- Part-Machine Formation, Clustering Techniques, Group Technology, Cell Formation

\section{INTRODUCTION}

The objective of all industries is to increase the efficiency through improved productivity. In order to accomplish this task, there is a wide variety methodologies used in industries. Many manufacturing firms which satisfy their customers while operating job shop production system have recently had to rethink because of the superiority of group technology (GT) philosophy of cellular manufacturing [1]. According to that, in cellular manufacturing system (CMS), group technology (GT) could recognize similar parts and cluster term into part families depending upon its manufacturing designs features and geometric shapes. The Cell Formation problem has long been identified in the concept of Cellular Manufacturing which begins with two fundamental task, 1) machine-cell formation, where similar machines are grouped and dedicated to manufacture partfamilies,2) part family construction, where parts with similar design, features, attributes, shapes grouped and manufactured within a cell[2]. The CF problems are represented by machine-part incidence matrix, where element presented as 0/1. As shown in Fig.1

Various approaches to cell formation have since been reported and fall under one of the six major classification: array-based clustering, similarity coefficient, mathematical programming, graph and network, heuristic and combinatorial optimization. The similarity coefficient approach was first suggested by McAuley. The basis of similarity coefficient is to calculate similarity between each pair of machines and then to group the machine into cells based on their similarity measurements [3]. Machine-part grouping problem is based on production flow analysis, in which the machine-part production cells are formed by permutting rows and columns of the machine-part mapping in the form of $\{0-1\}$ incidence matrix. Some the methods are rank order clustering, bond energy algorithm etc.

\begin{tabular}{|l|l|l|l|l|l|} 
& $\mathbf{P 1}$ & $\mathbf{P 2}$ & $\mathbf{P 3}$ & $\mathbf{P 4}$ & $\mathbf{P 5}$ \\
\hline $\mathbf{M}_{\mathbf{1}}$ & 0 & 1 & 1 & 0 & 1 \\
\hdashline $\mathbf{M}_{\mathbf{2}}$ & 1 & 0 & 0 & 1 & 1 \\
\hdashline $\mathbf{M}_{\mathbf{3}}$ & 0 & 0 & 1 & 0 & 1 \\
\hdashline
\end{tabular}

Fig.1 Machine-part incidence matrix

The array based rank order clustering techniques for partmachine formation and their performance metrics used in this study. In group technology, machines used to produce a family of parts should be grouped together in a cell [4]. The process of forming cell is known as machine part grouping. This results in each of the individual part and components families being managed easily in the industries. 


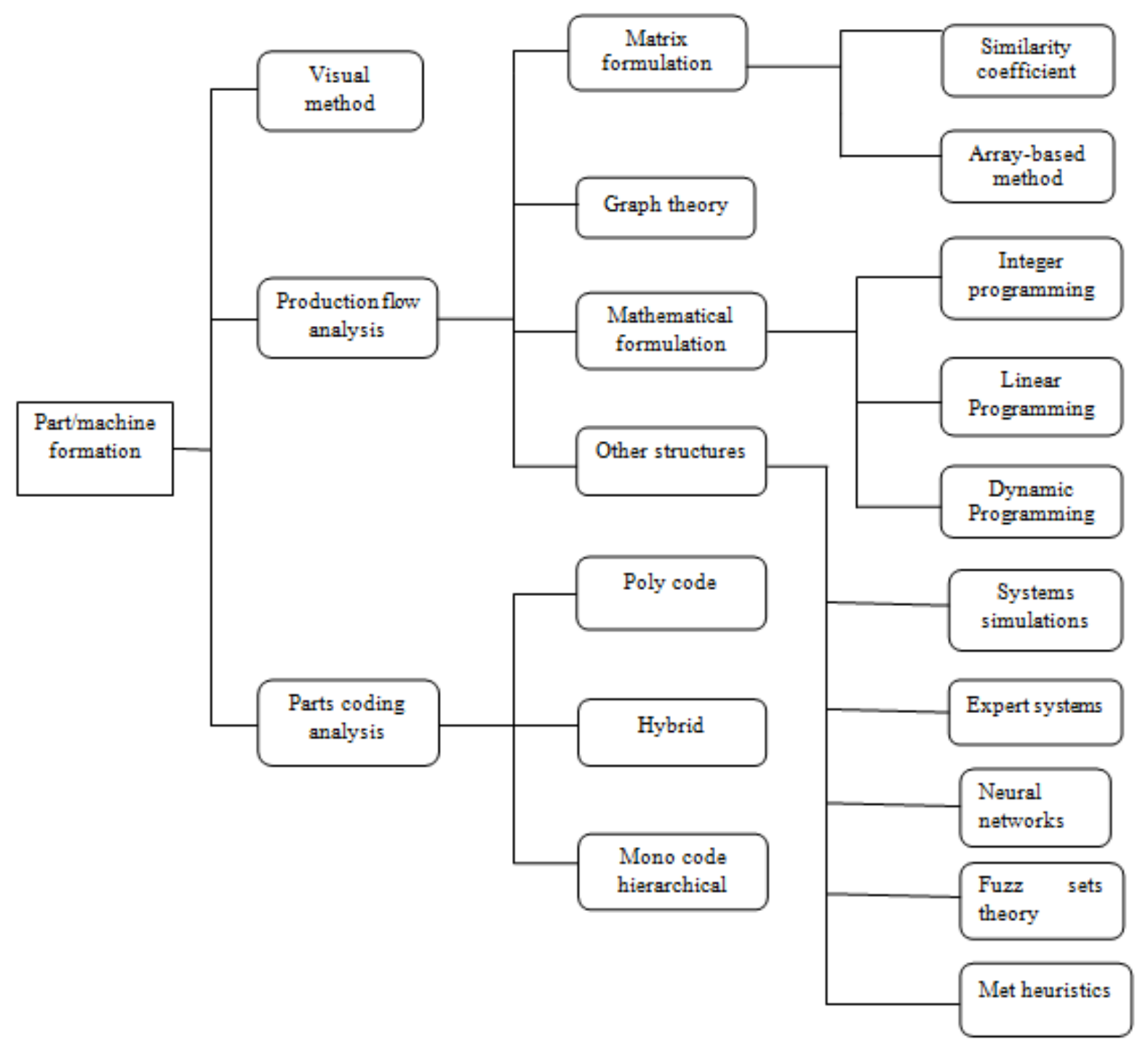

Fig.2 Methods of group formation

\section{METHODOLOGY}

\subsection{Rank order cluster (ROC) algorithm}

The ROC algorithm was developed by J.R. King (1980) and is based on the concept of production flow analysis. The effective methodology and part family/machine cell formation problem using rank order clustering algorithm [5].It is an efficient and easy to use algorithm for grouping machines into cells. ROC works by reducing the partmachine incidence matrix to a set of diagonalized blocks that represent part families and associated machine groups. The algorithm consists of the following steps:

\section{Steps in ROC algorithm}

- Each row, assign binary weights and calculate decimal equivalent.

- Rank the rows in order of decreasing valve. That is, the rows with the highest decimal equivalent are considered to have the highest rank 1 among the rows and so on.

- Numbering from top to bottom, check whether the current order of rows is the same.

- Rearrange the rows of the matrix rank wise.

- For each column, assign binary weights and calculate decimal equivalents.

- Rank the column in order of decreasing valve.

- Numbering from left to right, check whether the current order of column.Rearrange the column of the matrix rank wise

- The final part-machine incidence matrix. Stop and print.

\subsection{Problem 1}

Effective ten parts and five machine formation using rank order clustering technique 
Table-1: Initial part-machine incidence matrix

\begin{tabular}{|c|c|c|c|c|c|c|c|c|c|c|}
\hline \multirow{2}{*}{ Machines } & \multicolumn{9}{|c|}{ Parts } & D \\
\cline { 2 - 11 } & A & B & C & D & E & F & G & H & I & J \\
\hline $\mathbf{M}_{\mathbf{1}}$ & 1 & 1 & 1 & 1 & 1 & & 1 & 1 & 1 & 1 \\
\hline $\mathbf{M}_{\mathbf{2}}$ & & 1 & 1 & 1 & & & & & 1 & 1 \\
\hline $\mathbf{M}_{\mathbf{3}}$ & 1 & & & & 1 & 1 & 1 & 1 & & \\
\hline $\mathbf{M}_{\mathbf{4}}$ & & 1 & 1 & 1 & & & & 1 & 1 & 1 \\
\hline $\mathbf{M}_{\mathbf{5}}$ & 1 & 1 & 1 & 1 & 1 & 1 & 1 & 1 & & \\
\hline
\end{tabular}

Step 1: For each row, calculate decimal equivalent and binary weights. Then rank the rows in order of decreasing valve

Table-2: calculating the ranking of rows and decimal equivalent

\begin{tabular}{|c|c|c|c|c|c|c|c|c|c|c|c|c|}
\hline \multirow{5}{*}{ Machines } & \multirow{2}{*}{\multicolumn{10}{|c|}{ Parts }} & \multirow{5}{*}{$\begin{array}{c}\text { Decimal } \\
\text { equivalent }\end{array}$} & \multirow{5}{*}{ Rank } \\
\hline & & & & & & & & & & & & \\
\hline & $\mathbf{A}$ & B & C & D & $\mathbf{E}$ & $\mathbf{F}$ & G & H & I & $\mathbf{J}$ & & \\
\hline & \multicolumn{10}{|c|}{ Binary weights } & & \\
\hline & $2^{9}$ & $2^{8}$ & $\mathbf{2}^{7}$ & $2^{6}$ & $2^{5}$ & $2^{4}$ & $2^{3}$ & $2^{2}$ & $2^{1}$ & $2^{0}$ & & \\
\hline $\mathbf{M}_{1}$ & 1 & 1 & 1 & 1 & 1 & & 1 & 1 & 1 & 1 & 1006 & 2 \\
\hline $\mathbf{M}_{2}$ & & 1 & 1 & 1 & & & & & 1 & 1 & 450 & 5 \\
\hline $\mathbf{M}_{3}$ & 1 & & & & 1 & 1 & 1 & 1 & & & 572 & 3 \\
\hline $\mathbf{M}_{4}$ & & 1 & 1 & 1 & & & & 1 & 1 & 1 & 454 & 4 \\
\hline $\mathbf{M}_{5}$ & 1 & 1 & 1 & 1 & 1 & 1 & 1 & 1 & & & 1020 & 1 \\
\hline
\end{tabular}

Step 2: From table 2, noted the decimal equivalent and rank

Table-3: Row arrangement

\begin{tabular}{|c|c|c|c|c|c|c|c|c|c|c|}
\hline \multirow{2}{*}{ Machines } & \multicolumn{10}{|c|}{ Parts } \\
\hline & $\mathbf{A}$ & B & $\mathrm{C}$ & D & $\mathbf{E}$ & $\mathbf{F}$ & G & $\mathbf{H}$ & I & $\mathbf{J}$ \\
\hline 5 & 1 & 1 & 1 & 1 & 1 & 1 & 1 & 1 & & \\
\hline 1 & 1 & 1 & 1 & 1 & 1 & & 1 & 1 & 1 & 1 \\
\hline 3 & 1 & & & & 1 & 1 & 1 & 1 & & \\
\hline 4 & & 1 & 1 & 1 & & & & 1 & 1 & 1 \\
\hline 2 & & 1 & 1 & 1 & & & & & 1 & 1 \\
\hline
\end{tabular}

Step 3: Rearrange the rows in rank wise

Table 4: Calculating decimal equivalent and rank column

\begin{tabular}{|c|c|c|c|c|c|c|c|c|c|c|c|}
\hline \multirow{2}{*}{ Machines } & \multicolumn{10}{|c|}{ Parts } & \multirow{2}{*}{$\begin{array}{l}\text { Binary } \\
\text { weight }\end{array}$} \\
\hline & $\mathbf{A}$ & $\mathbf{B}$ & $\mathbf{C}$ & D & $\mathbf{E}$ & $\mathbf{F}$ & $\mathbf{G}$ & $\mathbf{H}$ & I & $\mathbf{J}$ & \\
\hline 5 & 1 & 1 & 1 & 1 & 1 & 1 & 1 & 1 & & & $2^{4}$ \\
\hline 1 & 1 & 1 & 1 & 1 & 1 & & 1 & 1 & 1 & 1 & $2^{3}$ \\
\hline 3 & 1 & & & & 1 & 1 & 1 & 1 & & & $2^{2}$ \\
\hline 4 & & 1 & 1 & 1 & & & & 1 & 1 & 1 & $2^{1}$ \\
\hline 2 & & 1 & 1 & 1 & & & & & 1 & 1 & $2^{0}$ \\
\hline Decimal equivalent & 28 & 27 & 27 & 27 & 28 & 20 & 28 & 30 & 11 & 11 & \\
\hline Rank & 2 & 3 & 3 & 3 & 2 & 4 & 2 & 1 & 5 & 5 & \\
\hline
\end{tabular}

Step 4: For each column, calculate decimal equivalent and assign binary weights. Then arrange the rank of column in decreasing valve

Table 5: Rearranging column

\begin{tabular}{|c|c|c|c|c|c|c|c|c|c|c|}
\hline \multirow{2}{*}{ Machines } & \multicolumn{10}{|c|}{ Parts } \\
\hline & $\mathbf{H}$ & $\mathbf{A}$ & $\mathbf{E}$ & $\mathbf{G}$ & B & $\mathbf{C}$ & D & $\mathbf{F}$ & I & $\mathbf{J}$ \\
\hline 5 & 1 & 1 & 1 & 1 & 1 & 1 & 1 & 1 & & \\
\hline 1 & 1 & 1 & 1 & 1 & 1 & 1 & 1 & & 1 & 1 \\
\hline 3 & 1 & 1 & 1 & 1 & & & & 1 & & \\
\hline 4 & 1 & & & & 1 & 1 & 1 & & 1 & 1 \\
\hline 2 & & & & & 1 & 1 & 1 & & 1 & 1 \\
\hline
\end{tabular}

Step 5: Rearrange the column 


\subsection{Iteration 2}

Table 6: Calculating decimal equivalent and ranking of rows

\begin{tabular}{|c|c|c|c|c|c|c|c|c|c|c|c|c|}
\hline \multirow{4}{*}{ Machines } & \multicolumn{10}{|c|}{ Parts } & \multirow{4}{*}{$\begin{array}{c}\text { Decimal } \\
\text { equivalent }\end{array}$} & \multirow{4}{*}{ Rank } \\
\hline & $\mathbf{H}$ & $\mathbf{A}$ & $\mathbf{E}$ & $\mathbf{G}$ & B & $\mathbf{C}$ & D & $\mathbf{F}$ & $\mathbf{I}$ & $\mathbf{J}$ & & \\
\hline & \multicolumn{10}{|c|}{ Binary weights } & & \\
\hline & $2^{9}$ & $2^{8}$ & $2^{7}$ & $2^{6}$ & $2^{5}$ & $2^{4}$ & $2^{3}$ & $2^{2}$ & $2^{1}$ & $2^{0}$ & & \\
\hline 5 & 1 & 1 & 1 & 1 & 1 & 1 & 1 & 1 & & & 992 & 2 \\
\hline 1 & 1 & 1 & 1 & 1 & 1 & 1 & 1 & & 1 & 1 & 1019 & 1 \\
\hline 3 & 1 & 1 & 1 & 1 & & & & 1 & & & 964 & 3 \\
\hline 4 & 1 & & & & 1 & 1 & 1 & & 1 & 1 & 571 & 4 \\
\hline 2 & & & & & 1 & 1 & 1 & & 1 & 1 & 596 & 5 \\
\hline
\end{tabular}

Step 6: For each row, calculate decimal equivalent and assign binary digit. Then arrange the rank in decreasing valve

Table 7: Rearranging rows

\begin{tabular}{|c|c|c|c|c|c|c|c|c|c|c|}
\hline \multirow{2}{*}{ Machines } & \multicolumn{10}{|c|}{ Parts } \\
\cline { 2 - 13 } & H & A & E & G & B & C & D & F & I & J \\
\hline 1 & 1 & 1 & 1 & 1 & 1 & 1 & 1 & & 1 & 1 \\
\hline 5 & 1 & 1 & 1 & 1 & 1 & 1 & 1 & & & \\
\hline 3 & 1 & 1 & 1 & 1 & & & & 1 & & \\
\hline 4 & 1 & & & & 1 & 1 & 1 & & 1 & 1 \\
\hline 2 & & & & & 1 & 1 & 1 & & 1 & 1 \\
\hline
\end{tabular}

Step 7: Rearrange the rows

Table 8: Calculating the decimal equivalent and ranking columns

\begin{tabular}{|c|c|c|c|c|c|c|c|c|c|c|c|}
\hline \multirow{2}{*}{ Machines } & \multicolumn{10}{|c|}{ Parts } & \multirow{2}{*}{$\begin{array}{l}\text { Binary } \\
\text { weights }\end{array}$} \\
\hline & $\mathbf{H}$ & $\mathbf{A}$ & $\mathbf{E}$ & G & B & $\mathbf{C}$ & D & $\mathbf{F}$ & I & $\mathbf{J}$ & \\
\hline 1 & 1 & 1 & 1 & 1 & 1 & 1 & 1 & 1 & & & $2^{4}$ \\
\hline 5 & 1 & 1 & 1 & 1 & 1 & 1 & 1 & & 1 & 1 & $2^{3}$ \\
\hline 3 & 1 & 1 & 1 & 1 & & & & 1 & & & $2^{2}$ \\
\hline 4 & 1 & & & & 1 & 1 & 1 & & 1 & 1 & $2^{1}$ \\
\hline 2 & & & & & 1 & 1 & 1 & & 1 & 1 & $2^{0}$ \\
\hline $\begin{array}{l}\text { Decimal } \\
\text { equivalent }\end{array}$ & 30 & 28 & 28 & 28 & 27 & 27 & 27 & 20 & 11 & 11 & \\
\hline Rank & 1 & 2 & 2 & 2 & 3 & 3 & 3 & 4 & 5 & 5 & \\
\hline
\end{tabular}

Step 8: From table 8, it noted that column order differ above matrix

Table 9: Rearranging column

\begin{tabular}{|c|c|c|c|c|c|c|c|c|c|c|}
\hline \multirow{2}{*}{ Machines } & \multicolumn{10}{|c|}{ Parts } \\
\cline { 2 - 13 } & H & A & E & G & B & C & D & F & I & J \\
\hline 1 & 1 & 1 & 1 & 1 & 1 & 1 & 1 & 1 & & 1 \\
\hline 5 & 1 & 1 & 1 & 1 & 1 & 1 & 1 & & 1 & 1 \\
\hline 3 & 1 & 1 & 1 & 1 & & & & 1 & & 1 \\
\hline 4 & 1 & & & & 1 & 1 & 1 & & 1 & 1 \\
\hline 2 & & & & & 1 & 1 & 1 & & 1 & 1 \\
\hline
\end{tabular}

Step 9: Rearrange the column 
Table 10: Part-machine formation

\begin{tabular}{|c|c|c|c|c|c|c|c|c|c|c|c|c|}
\hline \multirow{4}{*}{ Machines } & \multicolumn{10}{|c|}{ Parts } & \multirow{4}{*}{$\begin{array}{c}\text { Decimal } \\
\text { equivalent }\end{array}$} & \multirow{4}{*}{ Rank } \\
\hline & $\mathbf{H}$ & $\mathbf{A}$ & $\mathbf{E}$ & $\mathbf{G}$ & $\mathbf{B}$ & $\mathrm{C}$ & $\mathbf{D}$ & $\mathbf{F}$ & $\mathbf{I}$ & $\mathbf{J}$ & & \\
\hline & \multicolumn{10}{|c|}{ Binary weights } & & \\
\hline & $2^{9}$ & $2^{8}$ & $2^{7}$ & $2^{6}$ & $2^{5}$ & $2^{4}$ & $2^{3}$ & $2^{2}$ & $2^{1}$ & $2^{0}$ & & \\
\hline 1 & 1 & 1 & 1 & 1 & 1 & 1 & 1 & 1 & & & 1020 & 1 \\
\hline 5 & 1 & 1 & 1 & 1 & 1 & 1 & 1 & & 1 & 1 & 1019 & 2 \\
\hline 3 & 1 & 1 & 1 & & & & & 1 & & & 900 & 3 \\
\hline 4 & & & & & 1 & 1 & 1 & & 1 & 1 & 597 & 4 \\
\hline 2 & & & & & 1 & 1 & 1 & & 1 & 1 & 595 & 5 \\
\hline
\end{tabular}

Step 10: From table 10, it noted that part and machine formation

Table 11: Machine-parts groupings

\begin{tabular}{|l|l|l|}
\hline Group No & Machine cluster & Components family \\
\hline 1 & Cell 1: $1,5,3$ & Part family 1: H,A,E,G and B \\
\hline 2 & Cell 2: 4,3 & Part family 2: C,D,F,I and J \\
\hline
\end{tabular}

\subsection{Performance metrics in cell operations}

Some of the equation developed in industry operation can be adapted to the operation of group technology cells. Suppose the cell consists of of $\mathrm{n}$ machines (work station) and produces a family of parts with $n_{f}$ family members. Let $i=a$ subscript to identify machines $(i=1,2,3 \ldots \ldots)$, and let $j=a$ subscript to identify family members $\left(j=1,2 \ldots n_{f}\right)$.[6] The production time of family member $\mathrm{j}$ on machine $\mathrm{I}$ is given by $\mathrm{T}_{\mathrm{pij}}$ which is determined as follows

$$
\mathrm{T}_{\mathrm{pij}}=\frac{\mathrm{T}_{\text {suij }}+\mathrm{Q}_{\mathrm{j}} \mathrm{T}_{\mathrm{cij}}}{\mathrm{Qj}}
$$

Where $T_{\text {suij }}=$ the setup or change over time to prepare for family member $\mathrm{j}$ on machine $i$, min; $\mathrm{T}_{\mathrm{cij}}=$ operation cycle time for family member $\mathrm{j}$, pc. Unlike conventional batch production, one would expect the $\mathrm{T}_{\text {suij }}$ valve to be minimal; in the ideal case, there would be no lost time for changeover in cellular manufacturing $\left(\mathrm{T}_{\text {suij }}=0\right)$. Similarly, batch quantity $\mathrm{Q}_{\mathrm{j}}$ would be low, perhaps a batch size of one $\left(\mathrm{Q}_{\mathrm{j}}=1\right)$. With these valves, $\mathrm{T}_{\mathrm{pij}}=\mathrm{T}_{\mathrm{cij}}$. However, equation (1) allows for changeover time between different family member, and for the family members, and for the family members to be run in batches if there is a change over time [7].

The production rate $\mathrm{R}_{\mathrm{pij}}$ for family member $\mathrm{j}$ on machine $i$ is the reciprocal of production time, multiplied by 60 to express it as an hourly rate:

$$
\mathrm{R}_{\mathrm{pij}}=\frac{60}{\mathrm{~T}_{\mathrm{pij}}}
$$

Let $\mathrm{f}_{\mathrm{ij}}=$ the fraction of time during steady state operation that machine $i$ is processing family member $\mathrm{j}$. under normal conditions, it follos that for each machine $i$.

$0<\Sigma \mathrm{f}_{\mathrm{ij}}<1$ where $0<\mathrm{f}_{\mathrm{ij}}<1$ for all $i$.
The valve of $\Sigma \mathrm{f}_{\mathrm{ij}}$ for each machine is the utilization of that machine within the cell. That is,

$$
\mathrm{U}_{\mathrm{i}}=\underset{\mathrm{J}}{\sum \mathrm{f}_{\mathrm{ij}}}
$$

Where $\mathrm{U}_{\mathrm{i}}=$ utilization of machine $i$. if $\Sigma \mathrm{f}_{\mathrm{ij}}=1$, the machine is fully utilized. More likely, $\Sigma f_{i j}$ will be less than 1 for at least some of the machines in the cell. The average utilization of the cell is the average of the machine utilization:

$$
\mathrm{U}=\frac{\sum_{\mathrm{i}=1}^{\sum \mathrm{fij}_{\mathrm{j}}}}{\mathrm{n}}=\frac{\sum_{\mathrm{j}}}{\mathrm{n}}
$$

Each family members is processed through $n_{\mathrm{oj}}$ operations (machines) in the cell. The production rate of the cell is given by

$$
\mathrm{R}_{\mathrm{p}}=\Sigma \quad \sum \frac{\mathrm{f}_{\mathrm{ij}} \mathrm{R}_{\mathrm{pij}}}{\mathrm{n}_{\mathrm{oij}}} \mathrm{i=1}
$$

Where $\mathrm{R}_{\mathrm{p}}=$ average hourly production rate $(\mathrm{pc} / \mathrm{hr})$ of the cell; $n_{o j}=$ the number of operations required to produce family member $\mathrm{j}$, and the other terms are defined earlier.

One of the advantages of cellular manufacturing is reduced lead time to get parts through the cell compared to a job shop. The manufacturing lead time is the sum of setup time, run time, and nonoperation time. The nonoperation time consists of waiting time and move time within the cell [8]. For any family member, this can be expressed as follows:

$$
\operatorname{MLT}_{\mathrm{j}}=\sum_{\mathrm{i}=1}^{\mathrm{n}_{\mathrm{oj}}}\left(\mathrm{T}_{\text {suij }}+\mathrm{Q}_{\mathrm{j}} \mathrm{T}_{\mathrm{cij}}+\mathrm{T}_{\text {noij }}\right)
$$


Where $\mathrm{MLT}_{\mathrm{j}}=$ manufacturing lead time for part family member $\mathrm{j}$, min; $\mathrm{T}_{\text {suij }}=$ setup (changeover) time for operation I on family member $\mathrm{j}, \mathrm{min} ; \mathrm{Q}_{\mathrm{j}}=$ batch quantity of family member $\mathrm{j}$ being processed in the cell, $\mathrm{pc} ; \mathrm{T}_{\mathrm{cij}}=$ cycle time for operation I on family member $\mathrm{j}, \mathrm{min} / \mathrm{pc} ; \mathrm{T}_{\text {noij }}=$ nonoperation time associated with operation $\mathrm{I}, \mathrm{min}$; and $\mathrm{i}=$ indicates the operation sequence in the processing: $i=1,2, \ldots, n_{\mathrm{oj}}$, one would expect the setup time to be minimal in a group technology cell, depending on how similar the family members are. The nonoperation time in a GT cell would also be expected to be significantly less than in a conventional job shop or batch production situation. The average manufacturing lead time for the part family is given by the following [9]

MLT $=\frac{\sum_{\mathrm{j}=1}^{\mathrm{nf}} \mathrm{MLT}_{\mathrm{j}}}{\mathrm{n}_{\mathrm{f}}}$

Where MLT =average manufacturing lead time for the $n_{f}$ family members and $\mathrm{MLT}_{\mathrm{j}}=$ lead time for family members $\mathrm{j}$ from above equation
The work-in-progress manufacturing within the cell can be determined from the production rate and manufacturing lead time.

$$
\mathrm{WIP}=\mathrm{R}_{\mathrm{p}}(\mathrm{MLT})
$$

Where WIP $=$ work-in-progress in the plant, $\mathrm{pc} ; \mathrm{R}_{\mathrm{p}}=$ average hourly production rate from above equation

\subsection{Problem 2}

A group technology cell has three machines and is used to process a family of four similar parts. The table below lists production quantities $\left(\mathrm{Q}_{\mathrm{j}}\right)$, production times $\left(\mathrm{T}_{\mathrm{pij}}\right)$ and machine fractions for each family $\left(f_{i j}\right)$. Assuming the nonoperation times $\left(\mathrm{T}_{\mathrm{no}}\right)$ is all the same at 30 min per machine

\begin{tabular}{|l|l|l|l|l|l|l|l|}
\hline & \multicolumn{3}{c}{ Machine 1 } & \multicolumn{4}{c|}{ Machine 2 } \\
\hline Part & $\mathrm{Q}_{\mathrm{j}}$ & $\mathrm{T}_{\mathrm{P} 1}(\mathrm{~min})$ & $\mathrm{F}_{1 \mathrm{j}}$ & $\mathrm{T}_{\mathrm{p} 2}(\mathrm{~min})$ & $\mathrm{F}_{2 \mathrm{j}}$ & $\mathrm{T}_{\mathrm{p} 3}(\mathrm{~min})$ & $\mathrm{F}_{3 \mathrm{j}}$ \\
\hline A & 1 & 3.0 & 0.2 & 4.5 & 0.3 & 2.25 & 0.15 \\
$\mathrm{~B}$ & 1 & 2.0 & 0.2 & 4.0 & 0.4 & 3.0 & 0.3 \\
$\mathrm{C}$ & 1 & 5.0 & 0.25 & 4.0 & 0.2 & 3.0 & 0.15 \\
$\mathrm{D}$ & 1 & 4.0 & 0.3 & 1.333 & 0.1 & 2.667 & 0.2 \\
\hline
\end{tabular}

\subsection{Solution}

Hourly production rate for each machine and family member were computed using equation (2). The quantities of each family member produced in $1 \mathrm{hr}$ were $Q_{i j}=f_{i j} R_{p i j}$. The total for each column represents the hourly output of all parts from each machine $(17.5 \mathrm{pc} / \mathrm{hr})$.

The MLT values were obtained from MLT $_{j}=T_{p 2 j}+T_{p 2 j}+$ $\mathrm{T}_{\mathrm{pj} j}+\mathrm{T}_{\mathrm{no}}$.

\begin{tabular}{|l|l|l|l|l|l|r|}
\hline $\mathrm{R}_{\mathrm{p} 1}$ & $\mathrm{R}_{\mathrm{p} 2}$ & $\mathrm{R}_{\mathrm{p} 3}$ & $\mathrm{Q}_{1}$ & $\mathrm{Q}_{2}$ & $\mathrm{Q}_{3}$ & MLT \\
\hline 20.00 & 13.33 & 26.67 & 4.00 & 4.00 & 4.00 & 99.75 \\
30.00 & 15.00 & 20.00 & 6.00 & 6.00 & 6.00 & 99.00 \\
12.00 & 15.00 & 20.00 & 3.00 & 3.00 & 3.00 & 102.00 \\
15.00 & 45.00 & 22.50 & 4.50 & 4.50 & 4.50 & 68.00 \\
\hline & & & & 17.50 & 398.75 \\
\hline \multicolumn{2}{|l}{ Average MLT $=$} \\
\hline
\end{tabular}

\section{RESULT AND CONCLUSION}

a) Hourly production rate for each machine and for the cell $\mathrm{R}_{\mathrm{p}}=\mathbf{1 7 . 5}$ parts/hr

b) Average manufacturing lead time $\mathrm{MLT}=99.7 \mathrm{~min}$

c) Utilization for each machine is given by $\Sigma f_{i j}$ for each machines i. Thus, $\mathrm{U}_{1}=0.95, \mathrm{U}_{2}=1.0, \mathrm{U}_{3}=0.80$. Average cell utilization $\mathrm{U}=0.917$

d) Average work-in-process WIP $=(17.5 \mathrm{parts} / \mathrm{hr})(1.661$ hr) $=29.1$ Parts

This paper tells about the part-machine formation problem using rank order clustering, Pearson's correlation coefficient and performance metrics on GT operation. The proposed method obtains better quality solutions by consuming lesser time and the above result shows that proposed measures has the ability to perform its productivity efficiently.

\section{REFERENCES}

[1] Chandrasekaran.M.P, and R. Rajagopalan, "ZODIAC: An algorithm for concurrent formation of part families and machine cell", International journal of production research, vol.25,1987,pp.835-850. 
[2] Black, J.T, "An overview of cellular manufacturing systems and comparison to conventional systems", industrial engineering, Nov 1983,pp.36-48

[3] Godfrey C Onwubolu, "Cell formation in group technology: A similarity order clustering techniques", sajie.journals, vol 20, pp.125-131.

[4] Peetu paul, Justin koshy, "Conversion of regular assembly line into cellular manufacturing layout", International journal of engineering and innovative technology, vol 2(7), jan 2013.

[5] M.murugan, V. selladurai, " Formation of machine cells/part families in cellular manufacturing system using ART- Modified single linkage clustering approach- A study", Jordan journal of mechanical and industrial engineering,vol 5(3), june 2011.

[6] V.satheeshkumar, K. Karthikeyan "Evaluation of cell formation algorithm and implementation of MOD-SLC algorithm as An effective cellular manufacturing in manufacturing industry", International journal of current engineering and technology, vol 5(5), jan 2012

[7] Tamal ghosh, pranab dan," An effective machine-part grouping algorithm to construct manufacturing cells", proceedings of conference on industrial engineering, feb 2011

[8] Jayant h. bhangale," Parametric studies in automobile manufacturing industry using cell focused plant layout simulation approach", European scientific journal, vol 9(9), 20012.

\section{BIOGRAPHIES}

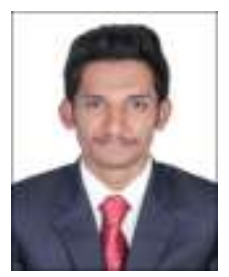

S.A. Puviyarasu is an active researcher in mechanical and automobile engineering. He had published many international research journals. He currently pursuing his bachelors in engineering (Mechanical Engineering), Dr. N.G.P Institute of technology, Coimbatore, Tamil nadu, India. Affiliated to Anna University, Chennai. Mail id: mrpuvi5@gmail.com 